\title{
Reduced expression of thyroid hormone receptor $\beta$ in human nonalcoholic steatohepatitis
}

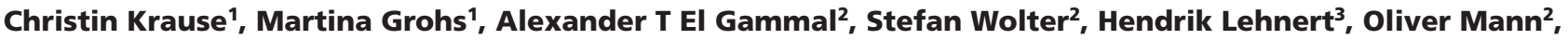 \\ Jens Mittag ${ }^{4}$ and Henriette Kirchner ${ }^{1}$
}

${ }^{1}$ Epigenetics \& Metabolism, Medical Department I, University of Lübeck, Lübeck, Germany

${ }^{2}$ Department of General, Visceral and Thoracic Surgery, University Medical Center Hamburg-Eppendorf, Hamburg, Germany

${ }^{3}$ Medical Department I, University of Lübeck, Lübeck, Germany

${ }^{4}$ Molecular Endocrinology, Medical Department I, University of Lübeck, Lübeck, Germany

Correspondence should be addressed to J Mittag or H Kirchner: jens.mittag@uni-luebeck.de or henriette.kirchner@uksh.de

\begin{abstract}
Hepatic thyroid hormone signaling has an important role in the development and progression of nonalcoholic steatohepatitis (NASH). While the systemic levels of thyroid hormone might remain stable, there is evidence that the intracellular signaling machinery consisting of transporters, deiodinases and receptors could be altered in NASH. However, clinical material from human liver biopsies of individuals with NASH has not been studied to date. In a cross-sectional study, we analyzed 85 liver biopsies from patients with different stages of NASH that underwent bariatric surgery. Using qPCR, we analyzed gene expression of thyroid hormone transporters NTCP (SLC10A1), MCT8 (SLC16A2) and OATP1C1 (SLCO1C1), thyroid hormone receptor $\alpha$ and $\beta$ (THRA and THRB) and deiodinase type I, II and III (DIO1, DIO2, DIO3). The expression was correlated with serum TSH, triglyceride, $\mathrm{HbA1C}$ and NASH score and corrected for age or gender if required. While $\mathrm{DIO}, \mathrm{DIO}$ and $\mathrm{SLCO1C1}$ were not expressed in human liver, we observed a significant negative correlation of THRB and DIO1 with age, and SLC16A2 with gender. THRB expression was also negatively associated with serum triglyceride levels and $\mathrm{HbA1c}$. More importantly, its expression was inversely correlated with NASH score and further declined with age. Our data provide unique insight into the mRNA expression of thyroid hormone transporters, deiodinases and receptors in the human liver. The findings allow important conclusions on the intrahepatic mechanisms governing thyroid hormone action, indicating a possible tissue resistance to the circulating hormone in $\mathrm{NASH}$, which becomes more prominent in advanced age.
\end{abstract}

Key Words
- thyroid hormone receptor
- thyroid hormone
transporter
- deiodinase
- liver

Endocrine Connections (2018) 7, 1448-1456

\section{Introduction}

Nonalcoholic fatty liver disease (NAFLD) is the most prevalent liver disease in Western countries, affecting for instance more than $10 \%$ of all adults in the United States. NAFLD encompasses a wide spectrum of different stages, ranging from steatosis with normal hepatic function to nonalcoholic steatohepatitis (NASH) and further to cirrhotic NASH and even hepatocellular carcinoma (for review see (1)). Several endocrine pathways are known to contribute to the development and progression of NAFLD (2), including thyroid hormone (TH). A strong connection between systemic hypothyroidism and NAFLD has been established in humans $(3,4,5)$ and rodents (6). Even in the euthryoid range, a link between NAFLD and higher free 3,3',5-triiodothyronine (fT3) https://ec.bioscientifica.com

https://doi.org/10.1530/EC-18-0499 (c) 2018 The authors Published by Bioscientifica Ltd

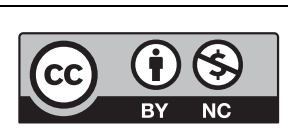

This work is licensed under a Creative Commons Attribution-NonCommercial 4.0 International License. 
and lower free thyroxine (fT4) levels has been described (7); however, the negative correlations of NAFLD with fT3 and fT4 in these euthyroid subjects suggest that the local hepatic levels of TH might be of even greater relevance for the disease pathogenesis than the systemic $\mathrm{TH}$ levels. In fact, a previous study on a small cohort in patients with NAFLD has found increased expression of the TH-inactivating enzyme deiodinase type 3 (DIO3) in human liver biopsies (8), suggesting that intracellular TH action might be reduced in this condition (9).

These findings fit well to the emerging concept that the levels of TH in the cell or organ might differ substantially from their concentrations in the circulation due to several cellular gatekeeping mechanisms. These mechanisms control for instance the entry of the hormone into the target cell through specific $\mathrm{TH}$ transport proteins such as MCT8 (monocarboxylate transporter 8, SLC16A2), MCT10 (SLC16A10) or OATP1C1 (organic anion transporting polypeptide 1c1, SLCO1C1), which have distinct and different expression patterns throughout the body (10). As a second step, intracellular deiodinase enzymes catalyze the conversion of THs, thus governing the activation (DIO1 and DIO2) or inactivation (DIO1 and DIO3) of the active hormone 3,3',5-triiodothyronine (T3) and its precursor 3,3',5,5'-tetraiodothyronine (thyroxine, T4). Finally, two different genes exist for nuclear TH receptors, THRA coding for TR $\alpha 1$ and THRB for TR $\beta$, which mediate the genomic effects of the hormone and stimulate or repress gene expression in target cells. With regard to the liver, it is well established that these gatekeeping mechanisms are predominantly governed by DIO1 and $\operatorname{TR} \beta$, while the role of the different transport proteins is less clear (11).

Targeting hepatic TH signaling has been a longterm goal in the field, evidenced by the ample number of TR $\beta$ specific compound such as GC-1, GC-24, KB141, KB2115 or MB07811 (12, 13, 14, 15). Despite their encouraging potential to induce favorable metabolic effects including lowering cholesterol levels, significant off-target effects were discovered during clinical trials (for review see (16)). Moreover, it was suggested that their liver-specific effect might be a consequence of transporter rather than TR $\beta$ specificity (17). However, most recently it was shown that a low-dose TH treatment is effective to reduce hepatic lipid content in NAFLD patients (18), underlining the great potential of $\mathrm{TH}$ in the treatment of the disease. Unfortunately, to date, little is known regarding the different gatekeeping mechanisms for $\mathrm{TH}$ action in the human liver and alterations that occur during NAFLD, which could affect therapeutic strategies to target hepatic
TH signaling in this condition. To test this hypothesis, we here investigate the expression of $\mathrm{TH}$ transporters, deiodinases and receptors in a unique collection of human liver biopsies from patients with different stages of NASH.

\section{Materials and methods}

\section{Study design and patients}

To establish a tissue bank for metabolic disorders, liver wedge biopsies were obtained in a standardized fashion from segment III during bariatric surgery of obese subjects at University Hospital Eppendorf (UKE, Hamburg). All participants signed an informed consent. The study was approved by the local ethics committee 'Ethik Komission der Ärztekammer Hamburg' (PV4889, 2015). As this was no direct recruitment for a study, the cohort is not matched for age and gender. Therefore, age and gender were tested as possible confounding factors and the results were corrected if necessary. NAFLD activity score was determined according to the current recommendations (19) by two expert pathologists. The patients were fasted for $6 \mathrm{~h}$ prior surgery, but had no dietary restrictions otherwise. Clinical parameters were measured at the time of the surgery by the Institut für Klinische Chemie und Laboratoriumsmedizin, Zentrum für Diagnostik, Universitätsklinikum Eppendorf, Hamburg, Germany according to the DIN EN ISO 15189:2014 certification. Glucose, cholesterol, HDL and triglycerides were determined using photometric assays, HbA1c was quantified using capillary electrophoresis or turbidimetric inhibition assays and folic acid and TSH were measured using luminescent oxygen channeling immunoassays (LOCI). The intra- and interassay variance for the TSH LOCI assay are typically in the range of 2.1 and 17\% respectively (20). Total T3 and T4 were determined from frozen serum samples using ELISAs (EIA-1781, DRG Diagnostics, Germany for T4 and DNOV053, NovaTec Immundiagnostica GmbH, Germany).

\section{RNA isolation and gene expression measurement by qPCR}

Whole-cell RNA was extracted from approximately $25 \mathrm{mg}$ of snap frozen liver using the MiRNeasy mini kit (QIAGEN) as indicated by the manufacturer and quantified spectrometrically. Two micrograms of RNA were reverse transcribed into cDNA using the SuperScript VILO cDNA synthesis kit (Invitrogen). Gene expression was measured by qPCR using FastStart Universal SYBR Green (Roche) and $0.25 \mu \mathrm{M}$ of each primer 
(sequences are available on request). The efficiency of all qPCR reactions was similar and above 95\%. Absence of genomic DNA was confirmed in a reaction without reverse transcriptase. Relative gene expression was calculated with the $\Delta \Delta \mathrm{Ct}$ method. Thirty-one potential housekeeping genes were tested with TaqMan Array Human Controls Plate (Applied Biosystems). According to the NormFinder algorithm (21), CASC3 was the best housekeeping gene and therefore all expression data were normalized to CASC3 expression. $\Delta \mathrm{Ct}$ values were normalized to a $0-1$ scale by $1-(\mathrm{xi}-\min (\mathrm{x})) /(\max (\mathrm{x})-\min (\mathrm{x})))$ for the visualization of gene expression, indicating 0 as lowest measured expression and 1 as highest measured expression.

\section{Statistics}

Correlations between gene expression (using $\Delta \mathrm{Ct}$ values) and the possible confounding factors were analyzed by Pearson's correlation for continuous parameters (age) and Spearman correlation as well as Student's t-test for ordinal parameters (gender), according to the Handbook of Biological Statistics (22). As DIO1 and THRB were affected by age and $S L C 16 A 2$ by gender, all subsequent $P$ values and effect sizes for these genes were corrected for age or gender respectively using a linear regression model. The respective figures contain the $P$ values calculated by Pearson's correlation for continuous parameters (TSH, serum triglycerides, HbA1c, blood glucose) or Spearman correlation for ordinal parameters (NASH score), as well as the age/gender corrected $P$ values derived from the linear regression model. All statistic calculations were performed by MATLAB, version R2016a (The MathWorks).

\section{Results}

As TH signaling has been connected to NASH development and progression, we hypothesized that the local control of $\mathrm{TH}$ levels might be pathologically altered in livers of patients with different stages of NASH. We therefore tested the expression of TH transporters, deiodinases and receptors in a unique collection of human liver biopsies (Table 1). Our data showed strong expression of both TH receptors, SLC16A2, SLC1OA1 and DIO1, whereas the mRNA levels of SLCO1C1, DIO2 and DIO3 were more than 10-fold lower, suggesting negligible biological relevance (Fig. 1A). As the cohort was controlled for BMI, but not for age and gender, we tested these two factors as possible confounders, revealing that the hepatic expression of SLC16A2 was significantly higher in females than in males (Fig. $1 \mathrm{~A}$, correlation $P=0.0317$, $t$-test $P=0.0264$ ), and DIO1 and THRB mRNA levels declined significantly with age (Fig. 1B, $P=0.0241$ for DIO1 and $P=0.0392$ for THRB). Remarkably, none of the genes were significantly correlated with serum levels of thyroid-stimulating hormone (TSH) or serum T3 or T4 concentrations (Table 2); however, almost all patients were in the euthyroid range. Interestingly, one patient was severely hypothyroid, but had inconspicuous DIO1 mRNA expression (Fig. 1C and Supplementary Fig. 1A, see section on supplementary data given at the end of this article).

We then tested whether the expression was correlated to systemic markers of lipid metabolism, revealing that SLC16A2, DIO1 and THRB were negatively correlated with serum triglyceride levels, while SLC1OA1 and THRA were not affected (Fig. 2A and Supplementary Fig. 1B). However, when the respective confounding factors were used for correction, only the expression of THRB remained significantly correlated $\left(P_{\mathrm{a}}=0.0175\right)$. No correlation to LDL or total cholesterol was observed (data not shown). With regard to markers of glucose metabolism, hepatic DIO1 and THRB mRNA expression were negatively associated with HbA1c (Fig. 2B and Supplementary Fig. 1C), even after correction for age $\left(P_{\mathrm{a}}=0.0434\right.$ for DIO1 and $P_{\mathrm{a}}=0.0268$ for $T H R B)$. No association for any of the genes was observed with blood glucose concentrations (data not shown), except for $T H R B$, which however was not significant after correction for age (Supplementary Fig. 1C).

Finally, we tested for an association of NASH score with the respective genes. The analysis revealed that THRB mRNA expression was negatively associated with NASH score $\left(P=0.0084\right.$, after correction for age $\left.P_{\mathrm{a}}=0.0461\right)$, with lower expression in higher stages (Fig. 3A), while the other genes were not correlated (Supplementary Fig. 2A). The expression of THRB mRNA was also not correlated with APOF mRNA levels (Supplementary Fig. 2B), a molecular marker of fibrosis (23). Taken together, the data indicate that reduced $T H R B$ expression, which further declines with age, is connected to more progressed stages of NASH (Fig. 3B) and suggest an altered cellular responsiveness to TH during disease progression and aging (Fig. 3C).

\section{Discussion}

Our study is the first to comprehensively test the expression of genes gating local $\mathrm{TH}$ action in liver, including transporters, deiodinases and receptors in NAFLD patients. As liver samples cannot be obtained from healthy individuals due to ethical reasons (due to the risk https://ec.bioscientifica.com https://doi.org/10.1530/EC-18-0499 (c) 2018 The authors Published by Bioscientifica Ltd
This work is licensed under a Creative Commons Attribution-NonCommercial 4.0 International License. 
Table 1 Characteristics of the human patient cohort.

\begin{tabular}{|c|c|c|}
\hline Parameter & Unit & Mean \\
\hline Gender & $\mathrm{m} / \mathrm{f}$ & $24 / 61$ \\
\hline Age & years & 43.8 \\
\hline BMI & $\mathrm{kg} / \mathrm{m}^{2}$ & 52.2 \\
\hline $\mathrm{TSH}^{\mathrm{a}}$ & $\mathrm{mU} / \mathrm{L}$ & 2.5 \\
\hline T3 & $\mathrm{ng} / \mathrm{mL}$ & 0.9 \\
\hline T4 & $\mu \mathrm{g} / \mathrm{dL}$ & 5.4 \\
\hline Triglycerides & $\mathrm{mmol} / \mathrm{L}$ & 212 \\
\hline Total cholesterol & $\mathrm{mg} / \mathrm{dL}$ & 188 \\
\hline LDL & $\mathrm{mg} / \mathrm{dL}$ & 101 \\
\hline $\mathrm{HbA1c}$ & $\%$ & 6.5 \\
\hline Blood glucose & $\mathrm{mg} / \mathrm{dL}$ & 130 \\
\hline Diabetes $^{\mathrm{b}}$ & Diagnosed yes/no & $34 / 51$ \\
\hline Hypertonia & Diagnosed yes/no & $52 / 31$ \\
\hline NAFLD activity & Score & 2.8 \\
\hline NAS frequency & Score (number) & 0 (19), 1 (5), 2 (10), 3 (8), 4 (10), 5 (12), 6 (9) \\
\hline Fibrosis & Fib-4 score & 0.8 \\
\hline Fibrosis & Diagnosed yes/no & $39 / 45$ \\
\hline
\end{tabular}

\begin{tabular}{|c|c|c|c|}
\hline St. Dev & Min & Max & $n$ \\
\hline & & & 85 \\
\hline 12.8 & 22 & 72 & 85 \\
\hline 10.8 & 32.2 & 84.9 & 85 \\
\hline 5.0 & 0.1 & 45.7 & 80 \\
\hline 0.2 & 0.1 & 1.3 & 76 \\
\hline 1.3 & 2.7 & 9.1 & 76 \\
\hline 121 & 57 & 611 & 85 \\
\hline 41 & 109 & 367 & 85 \\
\hline 34 & 12 & 174 & 79 \\
\hline 1.9 & 4.3 & 11.8 & 85 \\
\hline \multirow[t]{3}{*}{64} & 75 & 367 & 85 \\
\hline & & & 85 \\
\hline & & & 83 \\
\hline 2.2 & 0 & 6 & 73 \\
\hline \multirow[t]{2}{*}{0.6} & 0.2 & 2.7 & 84 \\
\hline & & & 84 \\
\hline
\end{tabular}

a 16 of which are treated with thyroxine. ${ }^{b} 30$ of which are treated with insulin and/or metformin.

associated with a liver biopsy), our cohort is naturally limited to sick individuals, in this case exhibiting severe obesity requiring bariatric surgery. Consequently, the results cannot be compared to a healthy control group, but were used to correlate gene expression with the severity of NAFLD, i.e. NAFLD activity score. Therefore, the results might not be representative for NAFLD patients in general, but given that obesity is the major risk factor
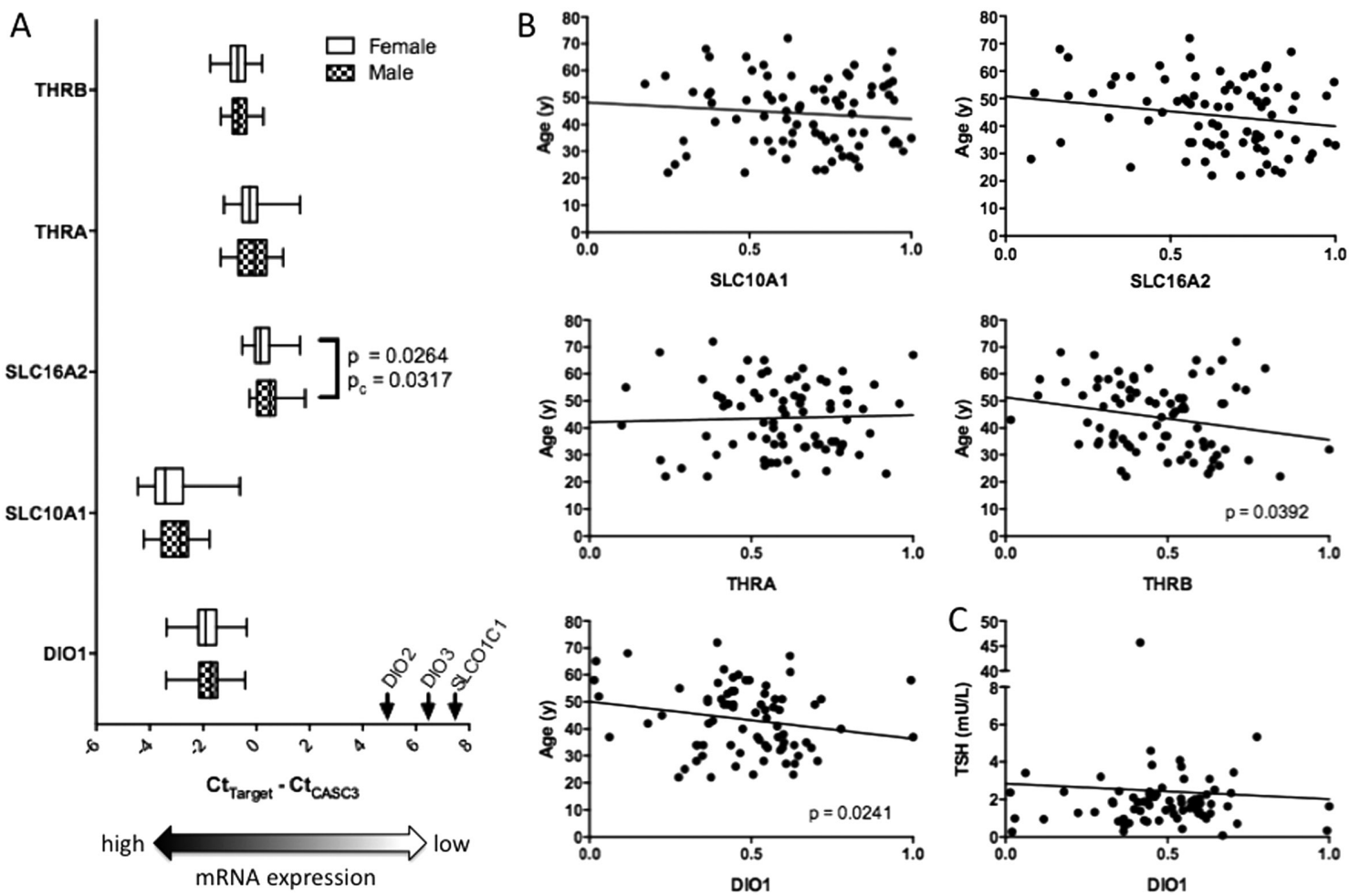

Figure 1

(A) Gene expression of thyroid hormone receptors, transporters and deiodinases in human liver biopsies of males and females, depicted as delta $\mathrm{Ct}$ to the housekeeping gene CASC3 with high expression levels on the left. (B) Correlation of NTCP (SLC10A1), MCT8 (SLC16A2), thyroid hormone receptor $\alpha$ and $\beta$ (THRA and THRB) and deiodinase type I (DIO1) mRNA expression with age. (C) Correlation of deiodinase type I (DIO1) mRNA expression with serum thyroid stimulating hormone (TSH).

$\begin{array}{lr}\text { https://ec.bioscientifica.com } & \text { ○ } 2018 \text { The authors } \\ \text { https://doi.org/10.1530/EC-18-0499 } & \text { Published by Bioscientifica Ltd }\end{array}$

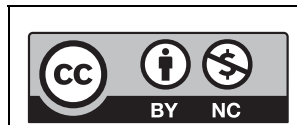

This work is licensed under a Creative Commons Attribution-NonCommercial 4.0 International License. 
Table 2 Detailed statistical analyses of the correlations in the study.

\begin{tabular}{|c|c|c|c|c|c|c|}
\hline & $\begin{array}{l}P \text { value } \\
\text { Pearson }\end{array}$ & $\begin{array}{c}P \text { value } \\
\text { Spearmann }\end{array}$ & $\begin{array}{l}P \text { value } \\
\text { corrected }\end{array}$ & $\begin{array}{l}\text { Correlation } \\
\text { coefficient }\end{array}$ & Effect size & $\begin{array}{l}\text { Effect size } \\
\text { corrected }\end{array}$ \\
\hline \multirow{2}{*}{\multicolumn{7}{|c|}{$\begin{array}{l}\text { Age } \\
\text { DIO1 }\end{array}$}} \\
\hline & & & & & & \\
\hline SLC10A1 & 0.3516 & & & -0.1035 & & \\
\hline SLC16A2 & 0.0827 & & & -0.1940 & & \\
\hline THRA & 0.7267 & & & 0.0394 & & \\
\hline THRB & $0.0392 *$ & & & -0.2282 & 7.9186 & \\
\hline \multirow{2}{*}{\multicolumn{7}{|c|}{ Gender }} \\
\hline DIO1 & & 0.4305 & & & & \\
\hline SLC10A1 & & 0.0770 & & 0.1952 & & \\
\hline SLC16A2 & & $0.0317 *$ & & 0.2389 & & \\
\hline THRA & & 0.4836 & & 0.0789 & & \\
\hline THRB & & 0.7439 & & 0.0366 & & \\
\hline \multicolumn{7}{|l|}{ BMI } \\
\hline DIO1 & 0.7884 & & & -0.0309 & & \\
\hline SLC10A1 & 0.9574 & & & -0.0059 & & \\
\hline SLC16A2 & 0.6879 & & & 0.0453 & & \\
\hline THRA & 0.6261 & & & 0.0549 & & \\
\hline THRB & 0.2827 & & & 0.1200 & & \\
\hline \multirow{2}{*}{\multicolumn{7}{|c|}{ TSH }} \\
\hline DIO1 & 0.7778 & & & & & \\
\hline SLC10A1 & 0.4601 & & & 0.0843 & & \\
\hline SLC16A2 & 0.3159 & & 0.4275 & 0.1158 & & \\
\hline THRA & 0.9453 & & & -0.0080 & & \\
\hline THRB & 0.7088 & & 0.5356 & 0.0430 & & \\
\hline \multicolumn{7}{|l|}{ T3 } \\
\hline DIO1 & 0.8783 & & 0.8920 & 0.0188 & & \\
\hline SLC10A1 & 0.9815 & & & -0.0028 & & \\
\hline SLC16A2 & 0.5604 & & 0.9793 & -0.0697 & & \\
\hline THRA & 0.7431 & & & -0.0396 & & \\
\hline THRB & 0.1590 & & 0.2548 & 0.1666 & & \\
\hline \multicolumn{7}{|l|}{$\mathrm{T} 4$} \\
\hline DIO1 & 0.2747 & & 0.8059 & -0.1334 & & \\
\hline SLC10A1 & 0.8695 & & & -0.0194 & & \\
\hline SLC16A2 & 0.2470 & & 0.3490 & -0.1372 & & \\
\hline THRA & 0.4991 & & & -0.0809 & & \\
\hline THRB & 0.2949 & & 0.5051 & -0.1234 & & \\
\hline Serum trigly & & & & & & \\
\hline DIO1 & 0.0097 & & 0.0706 & -0.2912 & 59.345 & \\
\hline SLC10A1 & 0.0611 & & & -0.2065 & & \\
\hline SLC16A2 & 0.0283 & & 0.0833 & -0.2437 & 56.014 & \\
\hline THRA & 0.8573 & & & 0.0203 & & \\
\hline THRB & 0.0024 & & $0.0175^{*}$ & -0.3303 & 110.33 & 81.401 \\
\hline $\mathrm{HbA} 1 \mathrm{c}$ & & & & & & \\
\hline DIO1 & 0.0041 & & $0.0434 *$ & -0.3218 & 0.9849 & 0.6305 \\
\hline SLC10A1 & 0.9033 & & & -0.0135 & & \\
\hline SLC16A2 & 0.0759 & & 0.1557 & -0.1983 & & \\
\hline THRA & 0.5801 & & & 0.0624 & & \\
\hline THRB & 0.0030 & & $0.0268 *$ & -0.3236 & 1.6621 & 1.1049 \\
\hline \multicolumn{7}{|c|}{ Blood glucose } \\
\hline DIO1 & 0.0917 & & 0.4940 & -0.1923 & & \\
\hline SLC10A1 & 0.8022 & & & -0.0279 & & \\
\hline SLC16A2 & 0.0705 & & 0.1653 & -0.2021 & & \\
\hline THRA & 0.6621 & & & 0.0493 & & \\
\hline THRB & 0.0114 & & 0.0843 & -0.2780 & 47.8810 & \\
\hline \multirow{2}{*}{\multicolumn{7}{|c|}{ NASH score }} \\
\hline DIO1 & & 0.2908 & 0.5044 & & & \\
\hline SLC10A1 & & 0.8663 & & 0.0202 & & \\
\hline SLC16A2 & & 0.7556 & 0.7036 & -0.0379 & & \\
\hline THRA & & 0.5448 & & 0.0725 & & \\
\hline THRB & & 0.0084 & 0.0461 * & -0.3106 & & \\
\hline
\end{tabular}

As DIO1 and THRB as dependent variables were found to be significantly affected by age, all subsequent correlations of these genes were corrected for age. Likewise, SLC16A2 was significantly affected by gender; hence, the subsequent analyses for this gene were corrected for gender. *: $P<0.05$

$\begin{array}{lr}\text { https://ec.bioscientifica.com } & \text { () } 2018 \text { The authors } \\ \text { https://doi.org/10.1530/EC-18-0499 } & \text { Published by Bioscientifica Ltd }\end{array}$



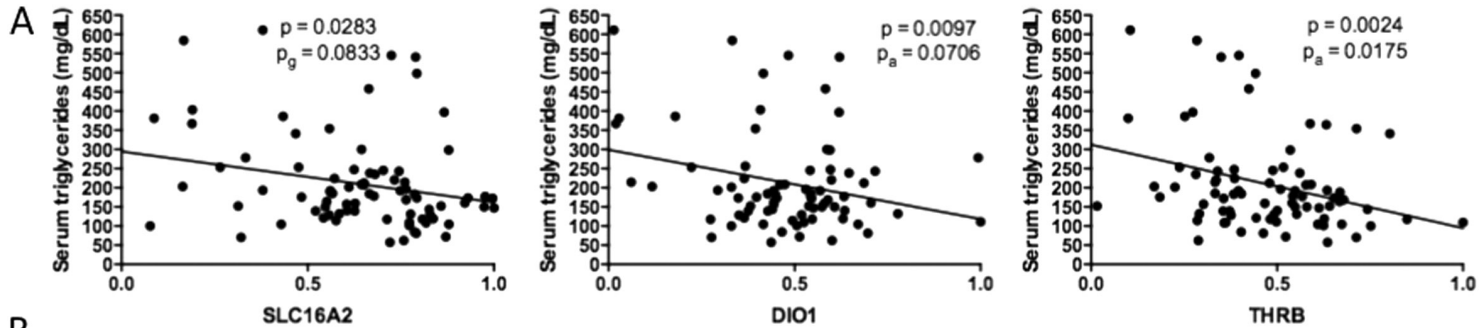

B
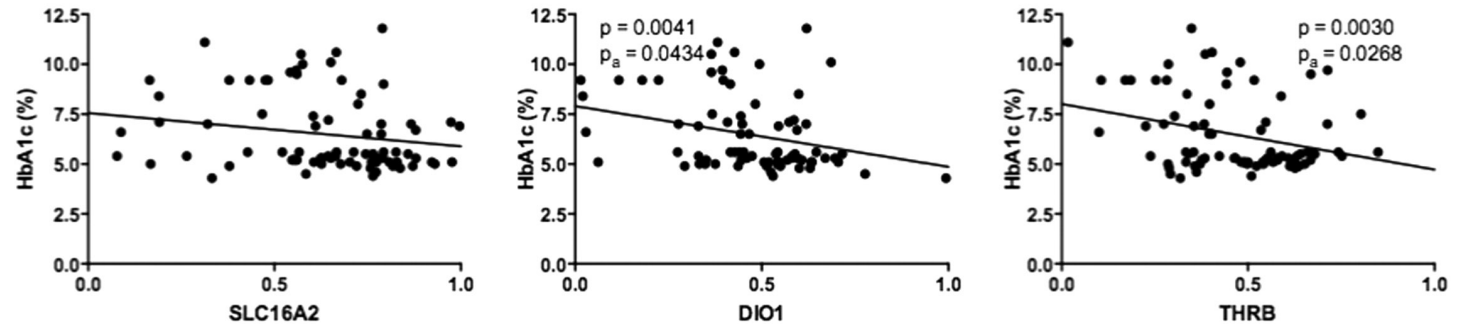

Figure 2

(A) Correlation of MCT8 (SLC16A2), deiodinase type I (DIO1) and thyroid hormone receptor $\beta$ (THRB) mRNA expression with serum triglyceride levels. (B) Correlation of MCT8 (SLC16A2), deiodinase type I (DIO1) and thyroid hormone receptor $\beta$ (THRB) mRNA expression with glycated haemoglobulin A1C (HbA1c). The respective raw and corrected $P$-values for age (a) or gender (g) are given in the figures.

for NAFLD (24), the findings are still of clinical relevance. Moreover, our results are currently limited to the mRNA expression; unfortunately, however, to the best of our knowledge reliable and properly validated commercial antibodies for $\mathrm{TH}$ receptors, deiodinases or transporters are currently not available (25).

\section{Hepatic gene expression in human liver}

As local changes in TH economy are expected in livers of patients with NAFLD (9), we tested the expression of the relevant genes in our biopsy collection. As expected, we could not detect SLCO1C1, DIO2 and DIO3 transcripts. DIO3 has been described in human fetal liver and adult livers of critically ill patients, but in line with our findings, it was reported to be absent in healthy adult human liver samples $(26,27)$. We identified hepatic expression of both TH receptor genes, which was not correlated to serum TSH, corroborating previous findings (28). Surprisingly, we did not find any correlation of DIO1 with serum TSH, T4 or T3, although the gene is known as a sensitive marker of peripheral TH status in the mouse (29) and also positively correlated with T3 in critically ill patients on enzyme and transcript level (30). However, only two patients in our cohort were outside the euthyroid reference range with TSH concentrations of $0.08 \mathrm{mU} / \mathrm{L}$ and $45.7 \mathrm{mU} / \mathrm{L}$ respectively, but their DIO1 transcript levels were not obviously altered. Interestingly, however, we observed lower DIO1 transcripts levels correlating with elevated HbA1c as long-term marker for diabetes, which concurs with previous animal studies showing low T3 and lower outer ring deiodination activity in type I diabetic rats (31) and mice (32). With regard to TH transporters, we observed a slightly higher expression of SLC16A2 (MCT8) in female individuals, potentially due to the fact that it is an X-chromosomal gene (10).

\section{Effects of aging}

In the general population, decreased thyroid function is associated with longevity (33). Moreover, older adults show a prevalence for subclinical hypothyroidism, but it is currently highly controversial whether a treatment is beneficial or harmful (34). Consequently, data on the local change in TH economy on the tissue level are highly relevant to understand the underlying causes and therapeutic consequences. Several studies on animal models are available, revealing decreased liver Slc16a2 and Dio1 expression in old rats (35), increased Slc1Oa1 but unaltered Slc16a2 transcripts in old mice (36) and lower DIO1 activities in several mouse models of aging (37). On the receptor level, no effect of age on Thra was observed, while a progressive increase in Thrb mRNA and total TR $\beta$ protein level was found in old rats; however, most remarkably, the nuclear levels of TR $\beta$ seemed to decline (35). Data on the human situation are scarce, reporting only an age-dependent decrease in THRB expression in peripheral blood mononuclear cells, presumably driven by changes in promoter methylation (38). Consequently, our data on decreased hepatic THRB and DIO1 expression

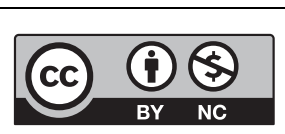

This work is licensed under a Creative Commons Attribution-NonCommercial 4.0 International License. 


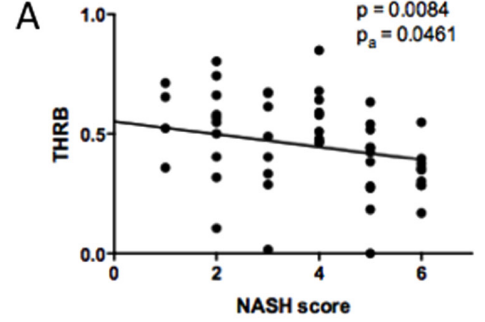

C

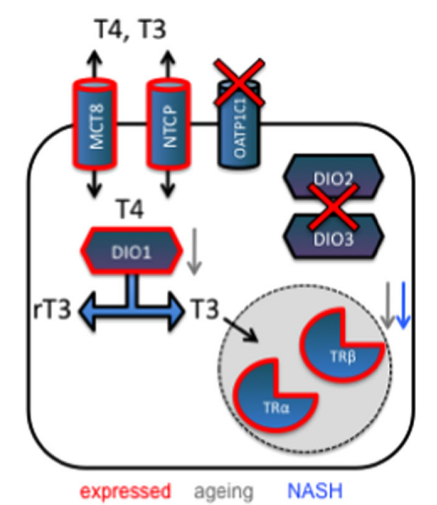

B

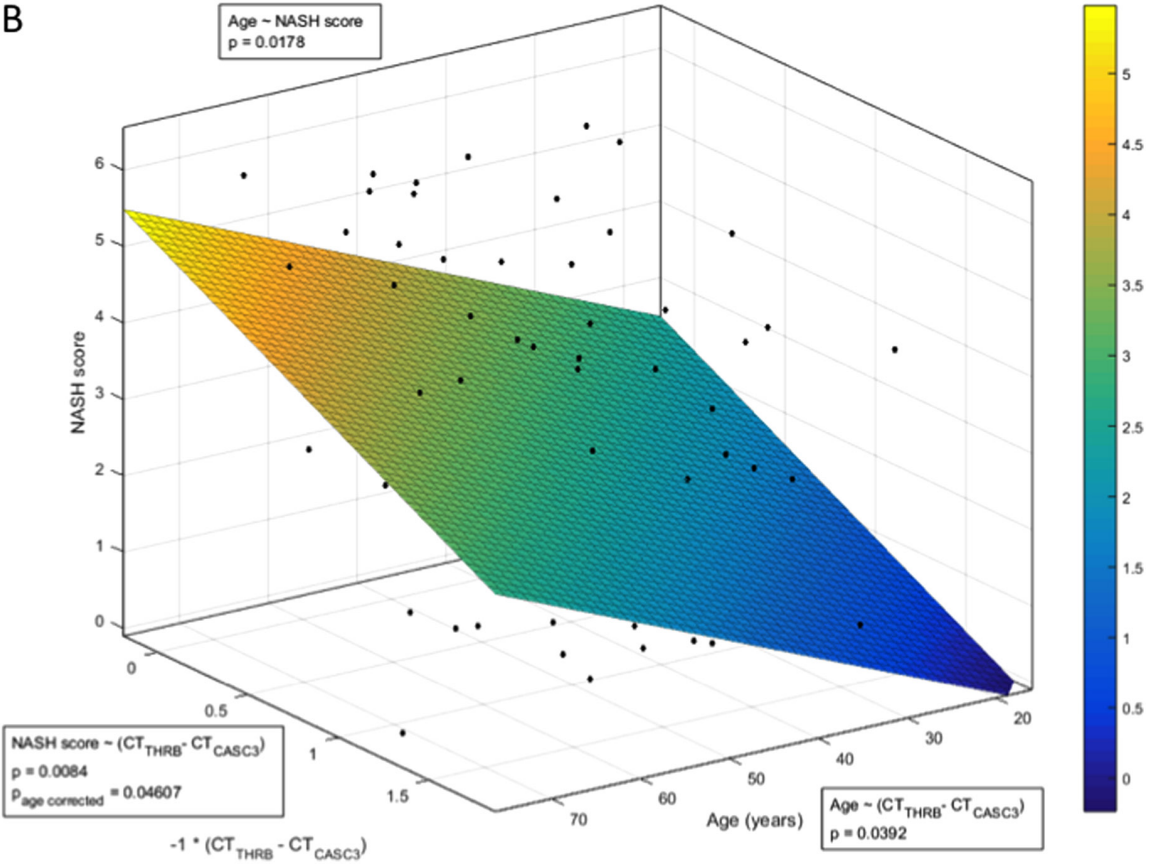

Figure 3

(A) Correlation of thyroid hormone receptor $\beta$ (THRB) mRNA expression with NASH score. The respective raw $P$ value and corrected for age (a) are given in the figure. (B) 3D model of the correlations between NASH score and age as well as THRB mRNA expression with the respective raw and corrected $P$ values. (C) Schematic overview of the changes in liver cell thyroid hormone economy with age and NASH. DIO, deiodinase; MCT8, SLC16A2; NTCP, SLC10A1; rT3, 3,3', 5'-triiodothyronine; SLCO1C1, OATP1C1; T3, 3,3',5-triiodothyronine; T4, thyroxine; TR, thyroid hormone receptor.

are of explicit biological relevance for the understanding of TH economy in the aging liver, as they suggest that the liver might become somewhat resistant to circulating TH.

\section{Nonalcoholic steatohepatitis}

Hypothyroidism is a known risk factor for NAFLD; however, the underlying mechanisms are complex likely involving a combination of direct hepatic effects and indirect actions via adipocytes (39). The role of hepatic deiodination in this context is controversial: some suggested a higher conversion of $\mathrm{T} 4$ as evidenced by an elevated T3/T4 ratio in patients with NAFLD (40), while others observed increased DIO3 and reduced DIO1 in NAFLD using immunohistochemistry on a small number of liver biopsies (8). However, our data from a larger cohort now suggest that at least the mRNA levels of DIO1 do not change over the course of the disease, while we could also not detect unusual expression of the other deiodinases.

That the expression of THRB decreases with higher stages of NASH is a potentially relevant finding, raising several questions for follow-up studies. Most importantly, using single-cell sequencing, it needs to be established whether the number of cells expressing THRB is reduced or whether our results represent an overall reduction in $T H R B$ expression. This could have clinical implications for the validity of THRB expression as additional parameter to determine the NASH score on the molecular level. Secondly, it needs to be tested, whether the lower transcript levels are a consequence of the disorder, for example, through the suppressing effect of higher serum triglyceride levels or whether they could be causally involved in NASH development. For this, one would first need to establish whether the observed amount of reduction in THRB mRNA translates to reduced protein levels and cellular resistance to TH. However, it is tempting to speculate that NASH progression and declining THRB expression jointly initiate a viscious cycle, which could be broken by (re) activation of hepatic TH signaling. This has been tried for a long time using TR $\beta$ selective compounds; unfortunately, to date, with little success due to severe side effects (16). More promising results have been obtained more recently with a liver targeted glucagon-T3 (41) or a low-dose T4 treatment in NAFLD patients (18). However, our data indicate that the efficiency of these approaches might depend on the stage of the disease, since at a certain point the cellular resistance might be irreversible due to the lack of reactivatable TR $\beta$. https://ec.bioscientifica.com https://doi.org/10.1530/EC-18-0499 (c) 2018 The authors Published by Bioscientifica Ltd
This work is licensed under a Creative Commons Attribution-NonCommercial 4.0 International License. 


\section{Supplementary data}

This is linked to the online version of the paper at https://doi.org/10.1530/ EC-18-0499.

\section{Declaration of interest}

The authors declare that there is no conflict of interest that could be perceived as prejudicing the impartiality of the research reported.

\section{Funding}

Our work was funded by the Deutsche Forschungsgemeinschaft (Emmy Noether Program KI1887/2-1, Heisenberg Program MI1242/2-2 and MI1242/5-1 in the framework of the SPP1629 Thyroid TransAct).

\section{References}

1 Michelotti GA, Machado MV \& Diehl AM. NAFLD, NASH and liver cancer. Nature Reviews Gastroenterology and Hepatology 201310 656-665. (https://doi.org/10.1038/nrgastro.2013.183)

2 Loria P, Carulli L, Bertolotti M \& Lonardo A. Endocrine and liver interaction: the role of endocrine pathways in NASH. Nature Reviews Gastroenterology and Hepatology 20096 236-247. (https://doi. org/10.1038/nrgastro.2009.33)

3 Chung GE, Kim D, Kim W, Yim JY, Park MJ, Kim YJ, Yoon JH \& Lee HS. Non-alcoholic fatty liver disease across the spectrum of hypothyroidism. Journal of Hepatology 201257 150-156. (https://doi. org/10.1016/j.jhep.2012.02.027)

4 Kim D, Kim W, Joo SK, Bae JM, Kim JH \& Ahmed A. Subclinical hypothyroidism and low-normal thyroid function are associated with nonalcoholic steatohepatitis and fibrosis. Clinical Gastroenterology and Hepatology 201816 123.e1-131.e1. (https://doi. org/10.1016/j.cgh.2017.08.014)

5 Ludwig U, Holzner D, Denzer C, Greinert A, Haenle MM, Oeztuerk S, Koenig W, Boehm BO, Mason RA, Kratzer W, et al. Subclinical and clinical hypothyroidism and non-alcoholic fatty liver disease: a cross-sectional study of a random population sample aged 18 to 65 years. BMC Endocrine Disorders 201515 41. (https://doi.org/10.1186/ s12902-015-0030-5)

6 Kahle M, Horsch M, Fridrich B, Seelig A, Schultheiss J, Leonhardt J, Irmler M, Beckers J, Rathkolb B, Wolf E, et al. Phenotypic comparison of common mouse strains developing high-fat diet-induced hepatosteatosis. Molecular Metabolism 20132 435-446. (https://doi. org/10.1016/j.molmet.2013.07.009)

7 Van Den Berg EH, Van Tienhoven-Wind LJ, Amini M, Schreuder TC, Faber KN, Blokzijl H \& Dullaart RP. Higher free triiodothyronine is associated with non-alcoholic fatty liver disease in euthyroid subjects: the Lifelines Cohort Study. Metabolism 201767 62-71. (https://doi.org/10.1016/j.metabol.2016.11.002)

8 Bohinc BN, Michelotti G, Xie G, Pang H, Suzuki A, Guy CD, Piercy D, Kruger L, Swiderska-Syn M, Machado M, et al. Repairrelated activation of hedgehog signaling in stromal cells promotes intrahepatic hypothyroidism. Endocrinology 2014155 4591-4601. (https://doi.org/10.1210/en.2014-1302)

9 Sinha RA, Singh BK \& Yen PM. Thyroid hormone regulation of hepatic lipid and carbohydrate metabolism. Trends in Endocrinology and Metabolism 201425 538-545. (https://doi.org/10.1016/j. tem.2014.07.001)

10 Friesema EC, Jansen J, Milici C \& Visser TJ. Thyroid hormone transporters. Vitamins and Hormones 200570 137-167. (https://doi. org/10.1016/S0083-6729(05)70005-4)

11 Yen PM. Physiological and molecular basis of thyroid hormone action. Physiological Reviews 200181 1097-1142. (https://doi. org/10.1152/physrev.2001.81.3.1097)
12 Baxter JD, Webb P, Grover G \& Scanlan TS. Selective activation of thyroid hormone signaling pathways by GC-1: a new approach to controlling cholesterol and body weight. Trends in Endocrinology and Metabolism 200415 154-157. (https://doi.org/10.1016/j. tem.2004.03.008)

13 Berkenstam A, Kristensen J, Mellstrom K, Carlsson B, Malm J, Rehnmark S, Garg N, Andersson CM, Rudling M, Sjoberg F, et al. The thyroid hormone mimetic compound KB2115 lowers plasma LDL cholesterol and stimulates bile acid synthesis without cardiac effects in humans. PNAS 2008105 663-667. (https://doi.org/10.1073/ pnas.0705286104)

14 Cable EE, Finn PD, Stebbins JW, Hou J, Ito BR, Van Poelje PD, Linemeyer DL \& Erion MD. Reduction of hepatic steatosis in rats and mice after treatment with a liver-targeted thyroid hormone receptor agonist. Hepatology 200949 407-417. (https://doi.org/10.1002/ hep.22572)

15 Vatner DF, Weismann D, Beddow SA, Kumashiro N, Erion DM, Liao XH, Grover GJ, Webb P, Phillips KJ, Weiss RE, et al. Thyroid hormone receptor-beta agonists prevent hepatic steatosis in fat-fed rats but impair insulin sensitivity via discrete pathways. American Journal of Physiology: Endocrinology and Metabolism $20133 \mathbf{3 0 5}$ E89-E100. (https://doi.org/10.1152/ajpendo.00573.2012)

16 Kowalik MA, Columbano A \& Perra A. Thyroid hormones, thyromimetics and their metabolites in the treatment of liver disease. Frontiers in Endocrinology 20189 382. (https://doi.org/10.3389/ fendo.2018.00382)

17 Kersseboom S, Van Gucht ALM, Van Mullem A, Brigante G, Farina S, Carlsson B, Donkers JM, Van De Graaf SFJ, Peeters RP \& Visser TJ. Role of the bile acid transporter SLC10A1 in liver targeting of the lipid-lowering thyroid hormone analog eprotirome. Endocrinology 2017158 3307-3318. (https://doi.org/10.1210/en.2017-00433)

18 Bruinstroop E, Dalan R, Cao Y, Bee YM, Chandran K, Cho LW, Soh SB, Teo EK, Toh SA, Leow MKS, et al. Low-dose levothyroxine reduces intrahepatic lipid content in patients with type 2 diabetes mellitus and NAFLD. Journal of Clinical Endocrinology and Metabolism 2018103 2698-2706. (https://doi.org/10.1210/jc.2018-00475)

19 Brunt EM, Kleiner DE, Wilson LA, Belt P, Neuschwander-Tetri BA $\&$ Network NCR. Nonalcoholic fatty liver disease (NAFLD) activity score and the histopathologic diagnosis in NAFLD: distinct clinicopathologic meanings. Hepatology 201153 810-820. (https:// doi.org/10.1002/hep.24127)

20 Monneret D, Guergour D, Vergnaud S, Laporte F, Faure P \& Gauchez AS. Evaluation of LOCI technology-based thyroid blood tests on the Dimension Vista analyzer. Clinical Biochemistry 201346 1290-1297. (https://doi.org/10.1016/j.clinbiochem.2012.11.011)

21 Andersen CL, Jensen JL \& Orntoft TF. Normalization of real-time quantitative reverse transcription-PCR data: a model-based variance estimation approach to identify genes suited for normalization, applied to bladder and colon cancer data sets. Cancer Research 2004 64 5245-5250. (https://doi.org/10.1158/0008-5472.CAN-04-0496)

22 Mcdonald JH. Handbook of Biological Statistics. 3rd ed. Baltimore, Maryland: Sparky House Publishing, 2014.

23 Ryaboshapkina M \& Hammar M. Human hepatic gene expression signature of non-alcoholic fatty liver disease progression, a metaanalysis. Scientific Reports 20177 12361. (https://doi.org/10.1038/ s41598-017-10930-w)

24 Fabbrini E, Sullivan S \& Klein S. Obesity and nonalcoholic fatty liver disease: biochemical, metabolic, and clinical implications. Hepatology 201051 679-689. (https://doi.org/10.1002/hep.23280)

25 Guan W, Guyot R \& Flamant F. Two protocols to study the interactions of thyroid hormone receptors with other proteins and chromatin. Methods in Molecular Biology 20181801 9-16. (https:// doi.org/10.1007/978-1-4939-7902-8_2)

26 Peeters RP, Wouters PJ, Kaptein E, Van Toor H, Visser TJ \& Van Den Berghe G. Reduced activation and increased inactivation of thyroid hormone in tissues of critically ill patients. Journal of Clinical https://ec.bioscientifica.com

https://doi.org/10.1530/EC-18-0499 (c) 2018 The authors Published by Bioscientifica Ltd
This work is licensed under a Creative Commons Attribution-NonCommercial 4.0 International License. 
Endocrinology and Metabolism 200388 3202-3211. (https://doi. org/10.1210/jc.2002-022013)

27 Richard K, Hume R, Kaptein E, Sanders JP, Van Toor H, De Herder WW, Den Hollander JC, Krenning EP \& Visser TJ. Ontogeny of iodothyronine deiodinases in human liver. Journal of Clinical Endocrinology and Metabolism 199883 2868-2874. (https://doi. org/10.1210/jcem.83.8.5032)

28 Chamba A, Neuberger J, Strain A, Hopkins J, Sheppard MC \& Franklyn JA. Expression and function of thyroid hormone receptor variants in normal and chronically diseased human liver. Journal of Clinical Endocrinology and Metabolism 199681 360-367. (https://doi. org/10.1210/jcem.81.1.8550778)

29 Zavacki AM, Ying H, Christoffolete MA, Aerts G, So E, Harney JW, Cheng SY, Larsen PR \& Bianco AC. Type 1 iodothyronine deiodinase is a sensitive marker of peripheral thyroid status in the mouse. Endocrinology 2005146 1568-1575. (https://doi.org/10.1210/ en.2004-1392)

30 Peeters RP, Wouters PJ, Van Toor H, Kaptein E, Visser TJ \& Van Den Berghe G. Serum 3,3', 5'-triiodothyronine (rT3) and 3,5,3'-triiodothyronine/rT3 are prognostic markers in critically ill patients and are associated with postmortem tissue deiodinase activities. Journal of Clinical Endocrinology and Metabolism 200590 4559-4565. (https://doi.org/10.1210/jc.2005-0535)

31 Gavin LA, Mcmahon FA \& Moeller M. The mechanism of impaired T3 production from T4 in diabetes. Diabetes 198130 694-699. (https://doi.org/10.2337/diab.30.8.694)

32 Tabata S, Nishikawa M, Toyoda N, Yonemoto T, Ogawa Y \& Inada M. Effect of triiodothyronine administration on reduced expression of type 1 iodothyronine deiodinase messenger ribonucleic acid in streptozotocin-induced diabetic rats. Endocrine Journal 199946 367-374. (https://doi.org/10.1507/endocrj.46.367)

33 Rozing MP, Houwing-Duistermaat JJ, Slagboom PE, Beekman M, Frolich M, De Craen AJ, Westendorp RG \& Van Heemst D. Familial longevity is associated with decreased thyroid function. Journal of Clinical Endocrinology and Metabolism 201095 4979-4984. (https:// doi.org/10.1210/jc.2010-0875)

34 Stott DJ, Rodondi N, Kearney PM, Ford I, Westendorp RGJ, Mooijaart SP, Sattar N, Aubert CE, Aujesky D, Bauer DC, et al. Thyroid hormone therapy for older adults with subclinical hypothyroidism. New England Journal of Medicine 2017376 2534-2544. (https://doi. org/10.1056/NEJMoa1603825)

35 Silvestri E, Lombardi A, De Lange P, Schiavo L, Lanni A, Goglia F, Visser TJ \& Moreno M. Age-related changes in renal and hepatic cellular mechanisms associated with variations in rat serum thyroid hormone levels. American Journal of Physiology: Endocrinology and Metabolism 2008294 E1160-E1168. (https://doi.org/10.1152/ ajpendo.00044.2008)

36 Engels K, Rakov H, Zwanziger D, Moeller LC, Homuth G, Kohrle J, Brix K \& Fuhrer D. Differences in mouse hepatic thyroid hormone transporter expression with age and hyperthyroidism. European Thyroid Journal 20154 81-86. (https://doi. org/10.1159/000381020)

37 Visser WE, Bombardieri CR, Zevenbergen C, Barnhoorn S, Ottaviani A, Van Der Pluijm I, Brandt R, Kaptein E, Van Heerebeek R, Van Toor H, et al. Tissue-specific suppression of thyroid hormone signaling in various mouse models of aging. PLOS ONE $2016 \mathbf{1 1}$ e0149941. (https://doi.org/10.1371/journal.pone.0149941)

38 Pawlik-Pachucka E, Budzinska M, Wicik Z, Domaszewska-Szostek A, Owczarz M, Roszkowska-Gancarz M, Gewartowska M \& PuzianowskaKuznicka M. Age-associated increase of thyroid hormone receptor beta gene promoter methylation coexists with decreased gene expression. Endocrine Research 201843 246-257. (https://doi.org/10.1 080/07435800.2018.1469648)

39 Ferrandino G, Kaspari RR, Spadaro O, Reyna-Neyra A, Perry RJ, Cardone R, Kibbey RG, Shulman GI, Dixit VD \& Carrasco N. Pathogenesis of hypothyroidism-induced NAFLD is driven by intra- and extrahepatic mechanisms. PNAS 2017114 E9172-E9180. (https://doi.org/10.1073/pnas.1707797114)

40 Bilgin H \& Pirgon O. Thyroid function in obese children with nonalcoholic fatty liver disease. Journal of Clinical Research in Pediatric Endocrinology 20146 152-157. (https://doi.org/10.4274/jcrpe.1488)

41 Finan B, Clemmensen C, Zhu Z, Stemmer K, Gauthier K, Muller L, De Angelis M, Moreth K, Neff F, Perez-Tilve D, et al. Chemical hybridization of glucagon and thyroid hormone optimizes therapeutic impact for metabolic disease. Cell 2016167 843.e14-857. e14. (https://doi.org/10.1016/j.cell.2016.09.014)

Received in final form 20 November 2018

Accepted 28 November 2018

Accepted Preprint published online 28 November 2018 https://ec.bioscientifica.com

https://doi.org/10.1530/EC-18-0499
() 2018 The authors Published by Bioscientifica Ltd

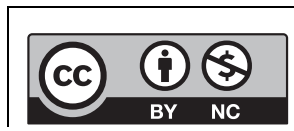

This work is licensed under a Creative Commons Attribution-NonCommercial 4.0 International License. 